\title{
Decadal Changes in Potassium, Calcium, and Magnesium in a Deciduous Forest Soil
}

\author{
D. W. Johnson* \\ Dep. of Natural Resource and Environ. Sci. \\ leischmann Agriculture Bldg. 370, \\ Univ. of Nevada \\ Reno, NV 89557
}

D. E. Todd, Jr.

Oak Ridge National Lab.

PO Box 2008

Oak Ridge, TN 37831

\section{F. Trettin}

U.S. Forest Service

2730 Savannah Hwy.

Charleston, SC 29414

\section{P. J. Mulholland \\ Oak Ridge National Lab. \\ PO Box 2008 \\ Oak Ridge, TN 37831}

Decadal changes in soil exchangeable $\mathrm{K}^{+}, \mathrm{Ca}^{2+}$, and $\mathrm{Mg}^{2+}$ concentrations and contents from 1972 to 2004 in eight intensively monitored plots on Walker Branch Watershed were compared with estimates of increments or decrements in vegetation and detritus. The results from these eight plots compared favorably with those from a more extensive set from 24 soil sampling plots sampled in 1972 and 2004. Increases in exchangeable $\mathrm{K}^{+}$were noted between 1972 and 1982, but few changes were noted between 1982 and 2004 despite significant increments in vegetation and detritus and significant potential losses by leaching. Total $\mathrm{K}$ contents of soils in the 0 - to 60 -cm sampling depth were very large and a slight amount of weathering could have replenished the $\mathrm{K}^{+}$lost from exchanges sites. With one notable exception, exchangeable $\mathrm{Ca}^{2+}$ and $\mathrm{Mg}^{2+}$ concentrations and contents decreased continuously during the sampling period. Decreases in exchangeable $\mathrm{Ca}^{2+}$ could be attributed mostly to increments in biomass and detritus, whereas decreases in exchangeable $\mathrm{Mg}^{2+}$ could not and were attributed to leaching. The major exception to these patterns was in the case of exchangeable $\mathrm{Ca}^{2+}$, where significant increases were noted in one plot and attributed to Ca release from the decomposition of Ca-rich coarse woody debris from oak (Quercus spp.) mortality. With minor exceptions, soils and changes in soils among the eight intensively sampled core plots were similar to those in a more extensive set of plots distributed across the watershed. This study shows that averaging among plots can mask significant and important spatial patterns in soil change that must be taken into account in assessing long-term trends.

Abbreviations: CWD, coarse woody debris; DBH, diameter at breast height.
$\mathrm{C}$ ase studies of long-term soil change are becoming more common in the literature and are adding substantially to our knowledge about this important subject (Bailey et al., 2005; Falkenggren-Grerup and Eriksson, 1990; FalkenggrenGrerup and Tyler, 1992; Hallbacken and Tamm, 1986; Johnson et al., 1988, 1994; Johnson and Todd, 1990; Knoepp and Swank, 1994; Richter et al., 1994; Richter and Markewitz, 2001; Trettin et al., 1999). In polluted regions of the world, atmospheric deposition may play a major role in causing soil acidification and decreases in exchangeable $\mathrm{K}^{+}, \mathrm{Ca}^{2+}$, and $\mathrm{Mg}^{2+}$ (Falkenggren-Grerup and Eriksson, 1990; Hallbacken and Tamm, 1986; Johnson and Todd, 1990). Uptake and accumulation in tree biomass can also be a significant cause of soil change, especially when the site is occupied by species with high $\mathrm{Ca}$ concentrations in their biomass (Alban, 1982; Johnson et al., 1988; Johnson and Todd, 1990; Richter and Markewitz, 2001; Trettin et al., 1999). It is important to quantify the effects of uptake and atmospheric deposition to the

Soil Sci. Soc. Am. J. 72:1795-1805

doi:10.2136/sssaj2007.0229

Received 20 June 2007.

*Corresponding author (dwj@cabnr.unr.edu).

(C) Soil Science Society of America

677 S. Segoe Rd. Madison WI 53711 USA

All rights reserved. No part of this periodical may be reproduced or transmitted in any form or by any means, electronic or mechanical, including photocopying, recording, or any information storage and retrieval system, without permission in writing from the publisher. Permission for printing and for reprinting the material contained herein has been obtained by the publisher. extent possible before making a judgment as to which factor is most responsible for the observed changes (Johnson, 2005).

Soils within eight core plots on Walker Branch Watershed have now been sampled four times in the last three decades, and we have attempted to reconcile the observed changes with estimates of uptake, atmospheric deposition, and leaching (Johnson et al., 1988; Johnson and Todd, 1990; Trettin et al., 1999). In the second sampling, we reported that exchangeable $\mathrm{Ca}^{2+}$ and $\mathrm{Mg}^{2+}$ in several core plots had declined during the period 1972 to 1982 (Johnson et al., 1988). Nutrient budget analyses at that time suggested that the declines in exchangeable $\mathrm{Ca}^{2+}$ content could be approximately accounted for by $\mathrm{Ca}$ accumulation in tree biomass while the declines in exchangeable $\mathrm{Mg}^{2+}$ could not, and we speculated that the latter changes were due to leaching. Both increases and decreases in exchangeable $\mathrm{K}^{+}$were noted in various plots with no clear overall trend.

In a later study, we measured leaching in selected plots and verified that biomass $\mathrm{Ca}$ increment exceeded leaching in plots where exchangeable $\mathrm{Ca}^{2+}$ declined (Johnson and Todd, 1990). We could neither confirm not refute the hypothesis that the declines in exchangeable $\mathrm{Mg}^{2+}$ were due to leaching, however, because leaching was extremely variable due to the high variability in soil sulfate retention (Johnson and Todd, 1990). Trettin et al. (1999) reported continued declines in soil exchangeable $\mathrm{Ca}^{2+}$ and $\mathrm{Mg}^{2+}$ in the third sampling in 1993 and once again attributed most of the $\mathrm{Ca}^{2+}$ decline to sequestration in trees and most of the $\mathrm{Mg}^{2+}$ decline to leaching. They also noted that decreases in exchangeable $\mathrm{Ca}^{2+}$ were less than what would be expected from increments in biomass in some 
plots, suggesting that deep rooting was supplementing $\mathrm{Ca}^{2+}$ supplies. Trettin et al. (1999) did not report the results for $\mathrm{K}^{+}$.

In this study, we sampled soils in the eight core plots on Walker Branch Watershed for the fourth time in 2004 and the remainder of the 24 soil sampling plots originally established in 1972 for the second time. The results of the $\mathrm{C}$ and $\mathrm{N}$ changes in soils and vegetation of these plots have been recently reported (Johnson et al., 2007). The objectives of the current study were threefold: (i) to compare changes in soil exchangeable $\mathrm{K}^{+}, \mathrm{Ca}^{2+}$, and $\mathrm{Mg}^{2+}$ from 1972 to 2004 in the eight core plots with those in the 24 plots originally established for the soil sampling database; (ii) to assess whether the trends seen between 1972 and 1993 continued into 2004; and (iii) to reconcile soil changes (if any) with estimates of above-soil $\mathrm{K}, \mathrm{Ca}$, and $\mathrm{Mg}$ sequestration in biomass and detritus. We hypothesized that:

1. The eight core plots are representative of the more extensive soil sampling plots established in 1972;

2. The changes reported by Trettin et al. (1999) for the third sampling in 1993 would continue to 2004; and

3 . As in the past, changes in exchangeable $\mathrm{Ca}^{2+}$ but not $\mathrm{Mg}^{2+}$ can be attributed to sequestration in above-soil biomass and detritus.

\section{MATERIALS AND METHODS}

\section{Site}

Walker Branch Watershed is located on Chestnut Ridge within the Department of Energy's Oak Ridge Reservation near Oak Ridge, TN. The watershed is at approximately 300- to 350-m elevation, has $14.5^{\circ} \mathrm{C}$ mean annual temperature, and approximately $135-\mathrm{cm}$ average annual precipitation, of which 43 to $48 \%$ is estimated to be lost as evapotranspiration (Henderson et al., 1978; Johnson and Van Hook, 1989; Johnson et al., 1988). The watershed is underlain by Knox group dolomite with several different formations occurring within the study area. Soils are mostly Ultisols (primarily Typic Paleudults) on geomorphically more stable upland interfluves and Inceptisols on steep slopes and alluvium. The upland residual soils are developed from deep (up to $30 \mathrm{~m}$ ) saprolite and saprolitic material, although areas of ancient and modern alluvium and colluvium of different ages also occur within the watershed boundary (Lietzke 1994).

Before World War II, land use on the 97.5-ha watershed consisted of a mix of forest, sustenance agriculture, and open woodland grazing. After the federal government acquired it in 1942, the watershed was allowed to return to a forested state and has not been disturbed since except by a fire in 1967 and by the invasion of insects such as the southern pine beetle (Dendroctonus frontalis Zimmermann). Major forest types originally identified by Grigal and Goldstein (1971) were characterized predominately as upland hardwoods (Quercus spp., Acer rubrum L., Carya spp.) with stands dominated by chestnut oak ( $Q$. prinus L.) and some intermixing of pine (Pinus echineta Mill. and $P$. virginiana Mill.) on ridges and old fields. Mesic coves and riparian zones are mainly yellow poplar (Lirodendron tulipifera L.) and American beech (Fagus grandifolia Ehrh.). Major changes in vegetation have taken place in many of these forest types, and some (in particular the pine type) no longer retain their original characteristics.

\section{Field Sampling}

In 1967, 298 vegetation inventory plots were established on the Walker Branch Watershed as per the protocol of Grigal and Goldstein (1971) and Harris et al. (1973). A nested set of three circular concentric plots $(0.004,0.04$, and $0.08 \mathrm{ha})$ was established at each of the 298 plot locations. The diameter at breast height $(\mathrm{DBH}, 1.37 \mathrm{~m})$ of trees of 1.5 - to $9-\mathrm{cm}$ diameter was measured within the smallest (0.004-ha) plot, the DBH of trees of 9- to 24-cm diameter was measured in the next smallest (0.04-ha) plot, and the DBH of trees $>24 \mathrm{~cm}$ was measured in the largest plot.

As part of the original study, 24 of the 298 inventory plots were selected in 1972 to represent the major soil and forest types (pine, yellow poplar, oak-hickory, and chestnut oak) for forest floor and soil sampling (Henderson et al., 1978). Within each of these 24 soil sampling plots, a 12 - by $12-\mathrm{m}$ square grid was established and monumented with metal stakes for long-term forest floor and soil sampling. Beginning in 1972, the forest floor and soils were sampled in the spring from six randomly selected $1-\mathrm{m}^{2}$ subplots within each 12 - by 12-m soil sampling grid (Henderson and Harris, 1975; Henderson et al., 1978). In each subplot, all wood $>2.5 \mathrm{~cm}$ in diameter was collected within $1 \mathrm{~m}^{2}$. After woody material was removed, a $0.25-\mathrm{m}^{2}$ ring was used to define the area in which wood $<2.5 \mathrm{~cm}$ and $\mathrm{O} 1$ and O2 horizons were collected. In the subsequent (1982, 1993, and 2004) samplings, we followed the protocol of the original study, O1 litter defined as recognizable by species (equivalent to $\mathrm{Oi}$ ) and $\mathrm{O} 2$ as more highly decomposed (equivalent to Oe plus Oa). After removal of the forest floor, one soil core was taken in the center of each $1-\mathrm{m}^{2}$ sub-subplot with a 5-cm-diameter bucket auger in depth increments of $15 \mathrm{~cm}$ to a final depth of $60 \mathrm{~cm}$. Unfortunately, only the 0 - to 15 -

Table 1. Basic soil and vegetation characteristics of the eight intensively sampled study plots.

\begin{tabular}{|c|c|c|c|c|c|c|c|}
\hline Plot & $\begin{array}{l}\text { Geomorphic } \\
\text { setting }\end{array}$ & Soil series & Classification & Slope position & Slope & Aspect & Dominant species (current/original) \\
\hline & & & & & $\%$ & $\circ$ & \\
\hline 179 & saprolite & Fullerton silt loam & Typic Paleudult & $\begin{array}{l}\text { upper slope near ridge } \\
\text { top }\end{array}$ & 15 & 280 & chestnut oak/chestnut oak \\
\hline 107 & saprolite & $\begin{array}{l}\text { Fullerton cherty silt } \\
\text { loam }\end{array}$ & Typic Paleudult & secondary ridge top & 5.5 & 355 & oak-hickory/oak-hickory \\
\hline 237 & saprolite & Fullerton silt loam & Typic Paleudult & $\begin{array}{l}\text { midslope, slight } \\
\text { depression }\end{array}$ & 16 & 135 & chestnut oak, white oak/chestnut oak \\
\hline 98 & cove & $\begin{array}{l}\text { Claiborn cherty silt } \\
\text { loam }\end{array}$ & Humic Paleudult & toe & 10 & 130 & yellow poplar, white oak/yellow poplar \\
\hline 281 & cove & Claiborn silt loam & Humic Paleudult & toe & 24 & 65 & yellow poplar/yellow poplar \\
\hline 26 & doline-saprolite & Fullerton silt loam & Typic Paleudult & midslope & 5 & 260 & yellow poplar/shortleaf pine \\
\hline 42 & colluvium & Fullerton silt loam & Typic Paleudult & ridge top & 13.5 & 160 & $\begin{array}{l}\text { red oak, chestnut oak, white oak/ } \\
\text { oak-hickory }\end{array}$ \\
\hline 91 & chert bed & $\begin{array}{l}\text { Bodine cherty silt } \\
\text { loam }\end{array}$ & Typic Paleudult & $\begin{array}{l}\text { secondary narrow ridge } \\
\text { top }\end{array}$ & 12.5 & 110 & oak-hickory/oak-hickory \\
\hline
\end{tabular}


and $45-$ to $60-\mathrm{cm}$ samples were kept in this original sampling. The soil sampling plots were relocated in 2004 and sampled according to the same procedures (D.E. Todd being present at both samplings), except that all soil depths were collected, analyzed, and archived in sealed glass bottles from the 2004 sampling.

In later years (1982 and 1993), a subset of eight of the soil sampling plots (hereafter referred to as the core plots) was identified as representative of the various forest types, soil types, and geomorphic settings for more intensive temporal sampling. This subset of core plots has served as the basis for assessing long-term changes in soil chemical properties and nutrient cycling (Johnson et al., 1988; Trettin et al., 1999). Table 1 provides a brief summary of the geomorphic setting, soil series and classification, slope, aspect, landscape position, and both original and current (2004) dominant vegetation composition. Three plots (179, 107, and 237) occur on soils formed from saprolite weathered from dolomite. They are characterized by a silt loam surface overlying a clay loam argillic horizon. Vegetation on these plots was dominated by chestnut oak with lesser amounts of hickory (Plot 107) and white oak (Plot 237), and species composition changed little during the sampling period. Two of the plots (98 and 281) occur in cove positions near the base of slopes. Soils are derived from parent materials derived from colluvium from upper slope positions and are enriched in organic matter and nutrients from upslope deposits. Vegetation in these plots is dominated by yellow poplar with lesser amounts of white oak in Plot 98, and species composition changed little during the sampling period. Plot 26 is derived from saprolite weathered from dolomite and lies on the side of a doline (a collapse structure similar to a sinkhole but without an open swallow hole). Vegetation on this plot changed substantially during the sampling period from shortleaf pine to yellow poplar dominance. Plot 42 is derived from upper slope colluvial soils from dolomite. Vegetation in this plot changed from oak-hickory to predominantly oak, with substantial mortality of both hickory and chestnut oak during the sampling period. Plot 91 is characteristic of soils formed on chert beds and has a substantial (30-60\%) chert component. Vegetation in this plot was dominated by oak and hickory and did not change substantially during the sampling period.

Forest floor and soils were sampled in the core plots in 1982, 1993, and 2004 as described above and soil samples from all depths were analyzed and archived for future analysis in an oven-dried state in sealed glass bottles.

\section{Laboratory Preparation and Analysis}

Twigs, bark, and leaves were separated from $\mathrm{Oi}$ and $\mathrm{Oe}+\mathrm{Oa}$ samples before drying. Subsamples of wood, woody litter, and $\mathrm{O}$ horizon samples were oven dried to constant weight at $100^{\circ} \mathrm{C}$ while soil samples were dried at $60^{\circ} \mathrm{C}$. Litter samples were crushed and sieved at $2 \mathrm{~mm}$ to separate rocks from the Oe + Oa material. Litter samples were processed by grinding in a Tecator Cyclotec sample mill (FOSS North America, Eden Prairie, MN) and stored in glass containers until extraction and analysis. Subsamples of vegetation and litter components were analyzed for $\mathrm{K}, \mathrm{Ca}$, and $\mathrm{Mg}$ at A\&L Agricultural Laboratories, Modesto, CA. At A\&L, K, Ca, and Mg in vegetation and litter were analyzed by inductively coupled plasma emission spectroscopy (ICP) after microwave digestion using a $\mathrm{HNO}_{3}-\mathrm{H}_{2} \mathrm{O}_{2}$ digestion mixture.

Soil samples were crushed and sieved at $2 \mathrm{~mm}$ to separate the soil from the coarse fraction. All soils, including archived samples from 1972, 1982, and 1993, were analyzed for exchangeable $\mathrm{Ca}^{2+}, \mathrm{Mg}^{2+}$, and $\mathrm{K}^{+}\left(10 \mathrm{~g}\right.$ soil in $50 \mathrm{~mL}$ of $1 \mathrm{~mol} \mathrm{~L}^{-1} \mathrm{NH}_{4} \mathrm{OAc}$ followed by ICP analyses) at A\&L Agricultural Laboratories. Ten percent blind duplicate samples were included in the analysis. Only the results from the current (2005) analysis were used in this comparison of laboratory bias. Some older samples had been depleted to $<1 \mathrm{~g}$ by previous analyses, resulting in complete analyses in 23 of 24 possible comparisons in the 0 - to $15-\mathrm{cm}$ depth and 19 of 24 in the 45 - to $60-\mathrm{cm}$ depth for the 1972 to 2004 data set.

\section{Biomass and Nutrient Content Calculations}

Changes in biomass (live, standing dead, and downed and dead) were estimated from measurements of $\mathrm{DBH}$ on 0.04 -ha nested plots (Johnson and Van Hook 1989) using allometric equations established by Harris et al. (1973). Vegetation nutrient contents were estimated from these mass data and nutrient concentrations obtained by destructive sampling on Walker Branch Watershed (Henderson et al., 1978) and the Chestnut Ridge whole-tree harvest site (Johnson et al., 1982). For standing dead and downed and dead biomass (coarse woody debris, CWD), DBH measurements from the previous inventory were used to estimate biomass. More detailed descriptions of these procedures are found in the above publications.

Forest floor nutrient contents were estimated from dry mass measurements and nutrient analysis by horizon. Soil nutrient contents were estimated using current nutrient analysis of both 2004 and archived soil samples combined with bulk density and coarse fragment data from previous samplings (Johnson et al., 1988; Trettin et al., 1999)

\section{Statistical Analyses}

For watershed-level changes in soil exchangeable $\mathrm{K}^{+}, \mathrm{Ca}^{2+}$, and $\mathrm{Mg}^{2+}$, the concentration changes in the individual soil plots between 1972 and 2004 were analyzed using unpaired Student's $t$-tests (Microsoft Excel) because the individual soil samplings could not be co-located. Changes in the grand average of all soil plots were analyzed using paired Student's $t$-tests on the average values for each plot using Microsoft Excel. Paired $t$-tests were used in the latter analysis because the averages by plot were co-located in the same plots.

For changes in concentrations in the core plots, the effects of plot, year, and depth on soil concentrations in the eight core plots were analyzed using PROC GLM in SAS software (Version 9.1 for Windows, SAS Institute, Cary, NC). Statistical analyses of vegetation, forest floor, soil, and ecosystem $\mathrm{K}, \mathrm{Ca}$, and $\mathrm{Mg}$ contents were conducted using plot as a replicate because only one estimate of tree $\mathrm{K}$, $\mathrm{Ca}$, and $\mathrm{Mg}$ content was available per plot. The effects of plot and year on ecosystem contents were analyzed by using PROC GLM in SAS software, and pairwise comparisons of $\mathrm{K}, \mathrm{Ca}$, and $\mathrm{Mg}$ contents of various ecosystem components were conducted using least significant differences (Carmer and Swanson, 1973). Statistical significance was determined at $\alpha=0.05$.

\section{RESULTS AND DISCUSSION Watershed-Level Changes in Soil Exchangeable Potassium, Calcium, and Magnesium, 1972 to 2004}

The changes in soil exchangeable $\mathrm{K}^{+}, \mathrm{Ca}^{2+}$, and $\mathrm{Mg}^{2+}$ in the $\mathrm{A}(0-15 \mathrm{~cm})$ and $\mathrm{Bt}(45-60 \mathrm{~cm})$ horizons in the original soil plots and in the eight core plots between 1972 and 2004 are depicted in Fig. 1 and the grand averages (averages of all plot averages) are given in Table 2 . The changes in exchangeable $\mathrm{K}^{+}$were fairly consistent across the watershed, with increases in most plots, especially in the surface depths. In the 0 - to $15-\mathrm{cm}$ 

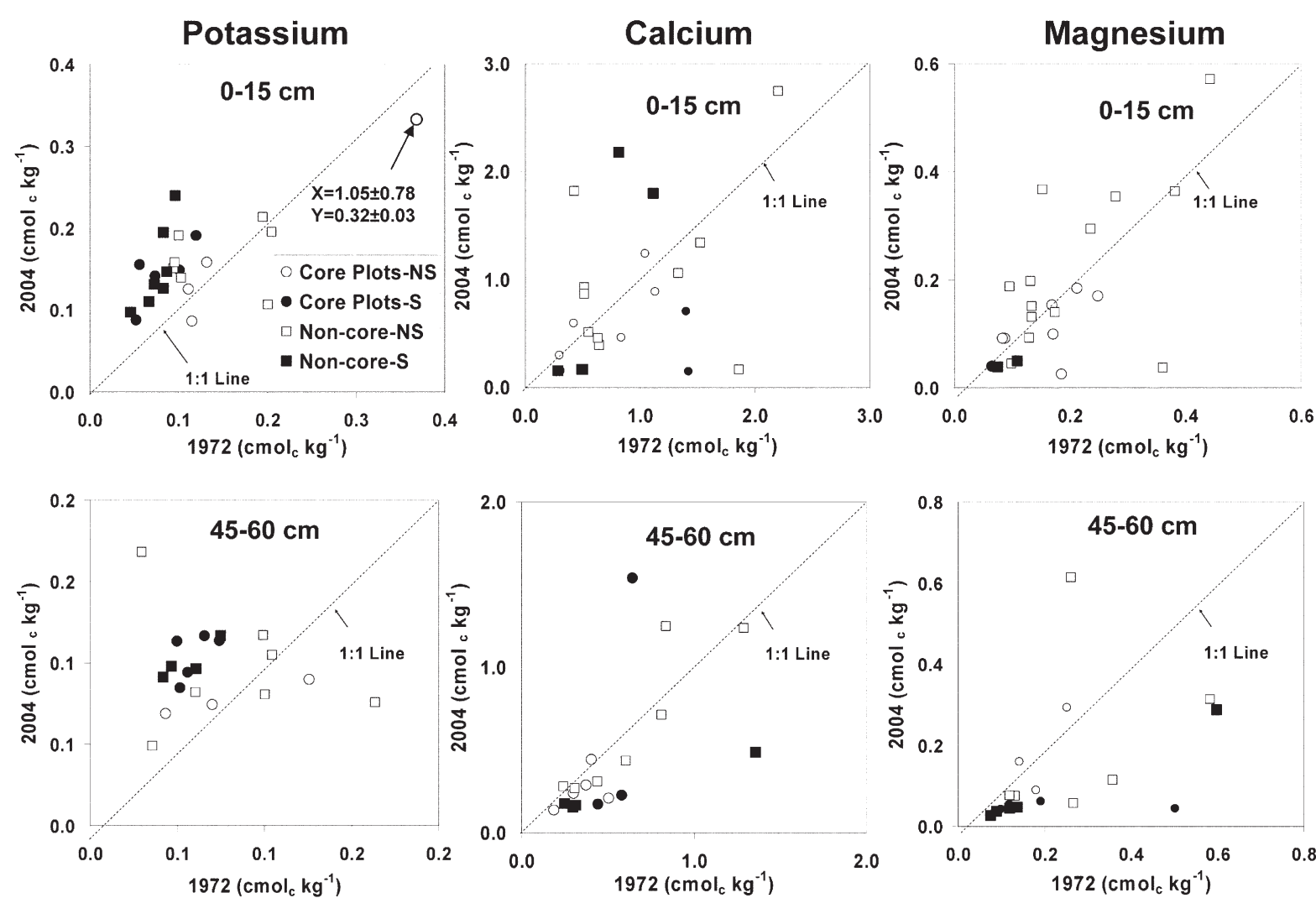

Fig. 1. Scatter plots of soil exchangeable $\mathrm{K}^{+}, \mathrm{Ca}^{2+}$, and $\mathrm{Mg}^{2+}$ concentrations in the $\mathrm{A}(0-15 \mathrm{~cm})$ and $\mathrm{Bt}(45-60 \mathrm{~cm})$ horizons in the original, noncore plots and the eight core plots in 1972 ( $x$ axis) and 2004 ( $y$ axis). Points falling above the 1:1 line indicate an increase, points falling below the 1:1 line indicate a decrease. Values for the eight core plots are shown as circles, values for the noncore plots are shown as squares. Solid symbols (S) indicate statistically significant differences, unpaired Student's $t$-test for the individual plots and paired $t$-tests for the averages among all plots $(P \leq 0.05)$; hollow symbols (NS) indicate no significant difference.

Table 2. Grand average (average of all plot averages) values for exchangeable $\mathrm{K}^{+}, \mathrm{Ca}^{2+}$, and $\mathrm{Mg}^{2+}$ in 1972 and 2004 among all plots and among the intensive core plots. Probability values for differences between all plots and intensive core plots for each year ( $P$ values, plots) and probability values for significant changes with time ( $P$ values, year) are given (Student's $t$-test).

\begin{tabular}{|c|c|c|c|}
\hline Nutrient and depth & 1972 & 2004 & $P$ values, year \\
\hline & $-\mathrm{cn}$ & $\mathrm{Ol}_{\mathrm{C}} \mathrm{kg}^{-1}$ & \\
\hline $\mathrm{K}^{+}(0-15 \mathrm{~cm})$ & & & \\
\hline All plots & $0.15 \pm 0.04$ & $0.16 \pm 0.01$ & 0.37 \\
\hline Core plots & $0.10 \pm 0.01$ & $0.14 \pm 0.01$ & 0.01 \\
\hline$P$ values, plots & 0.13 & 0.12 & \\
\hline $\mathrm{K}^{+}(45-60 \mathrm{~cm})$ & & & \\
\hline All plots & $0.07 \pm 0.01$ & $0.10 \pm 0.01$ & 0.01 \\
\hline Core plots & $0.07 \pm 0.01$ & $0.09 \pm 0.01$ & 0.02 \\
\hline$P$ values, plots & 0.37 & 0.40 & \\
\hline $\mathrm{Ca}^{2+}(0-15 \mathrm{~cm})$ & & & \\
\hline All plots & $0.88 \pm 0.11$ & $0.84 \pm 0.15$ & 0.38 \\
\hline Core plots & $0.86 \pm 0.17$ & $0.56 \pm 0.13$ & 0.07 \\
\hline$P$ values, plots & 0.45 & 0.09 & \\
\hline $\mathrm{Ca}^{2+}(45-60 \mathrm{~cm})$ & & & \\
\hline All plots & $0.54 \pm 0.08$ & $0.46 \pm 0.10$ & 0.17 \\
\hline Core plots & $0.43 \pm 0.05$ & $0.41 \pm 0.17$ & 0.44 \\
\hline$P$ values, plots & 0.13 & 0.39 & \\
\hline $\mathrm{Mg}^{2+}(0-15 \mathrm{~cm})$ & & & \\
\hline All plots & $0.18 \pm 0.02$ & $0.17 \pm 0.03$ & 0.29 \\
\hline Core plots & $0.15 \pm 0.02$ & $0.11 \pm 0.02$ & 0.03 \\
\hline$P$ values, plots & 0.19 & 0.05 & \\
\hline $\mathrm{Mg}^{2+}(45-60 \mathrm{~cm})$ & & & \\
\hline All plots & $0.23 \pm 0.04$ & $0.13 \pm 0.03$ & 0.01 \\
\hline Core plots & $0.22 \pm 0.05$ & $0.10 \pm 0.03$ & 0.04 \\
\hline$P$ values, plots & 0.44 & 0.25 & \\
\hline
\end{tabular}

depth, 10 of 23 soil plots analyzed and four of the eight core plots showed significant $(P<0.05$, Student's $t$-test $)$ increases in exchangeable $\mathrm{K}^{+}$concentrations between 1972 and 2004. The grand averages of exchangeable $\mathrm{K}^{+}$in the 23 soil plots and eight core plots did not differ significantly in either 1972 or 2004, but the changes between 1972 and 2004 did differ: there was a significant increase in the eight core plots, but no significant change in the average of the 23 soil plots. The lack of significant change in the 23 soil plots in the 0 - to $15-\mathrm{cm}$ depth was due to a significant outlier value (Fig. 1). The value of this outlier for 1972 was five times greater than any other value for that year and well beyond the range defined for extreme outliers $(x$ $>\mathrm{Q} 3+3 \mathrm{IQR}$, where $x=$ the value, $\mathrm{Q} 3=$ the third quartile, and IQR = interquartile range, Q3-Q1). The 2004 value for that same point was $60 \%$ higher than any other value for that year, and qualified as a mild outlier ( $x>\mathrm{Q} 3+1.5 \mathrm{IQR})$ (Renze, 2007). If this outlier is removed, the difference between the grand average values of exchangeable $\mathrm{K}^{+}$for $1972(0.10 \pm 0.01)$ and $2004(0.15 \pm 0.01)$ is highly significant $(P<0.001)$ for the entire data set as well as the eight core plots.

In the $45-$ to $60-\mathrm{cm}$ depth, eight of the 19 soil plots analyzed and five of the eight core plots showed significant increases in exchangeable $\mathrm{K}^{+}$. The grand averages of exchangeable $\mathrm{K}^{+}$of the 19 soil plots did not differ significantly from the grand average of the eight core plots in either 1972 or 2004, and the increases between 1972 and 2004 were significant in both cases. 


\section{Potassium}
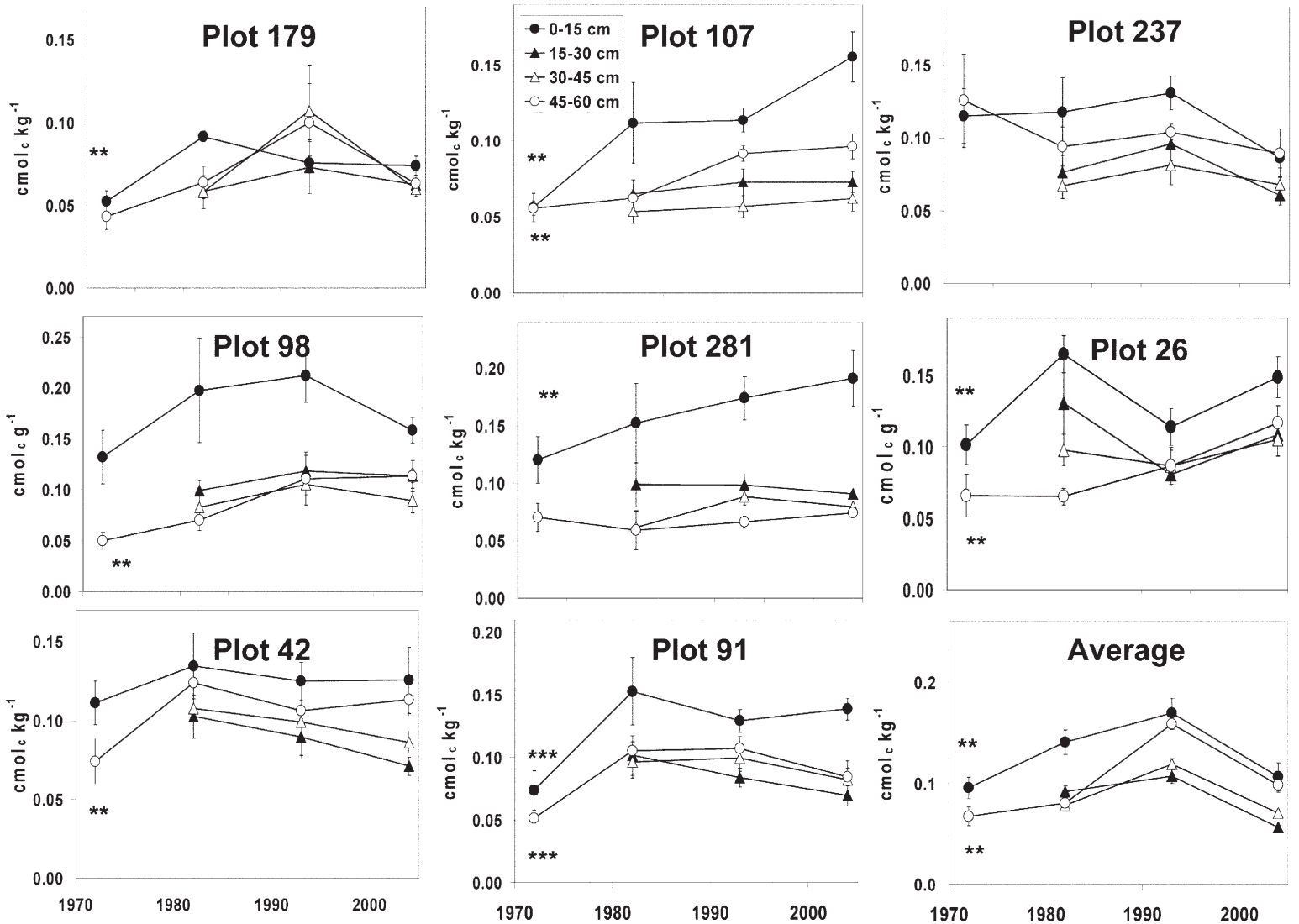

Fig. 2. Changes in soil exchangeable $\mathrm{K}^{+}$concentrations between 1972 and 2004 in the eight core plots. The panel labeled average shows the average values of all plots, using the plot average for each year. Standard errors are shown. Asterisks indicate significant differences between 1972 and 2004 analyses (0-15- and 45-60-cm depths only, unpaired Student's $t$-test, $* P \leq 0.05, * * P \leq 0.01)$.

The changes in exchangeable $\mathrm{Ca}^{2+}$ were highly variable across the watershed, with both increases and decreases. In the 0 - to 15 -cm depth, two of 23 soil plots showed significant increases and six showed significant decreases in exchangeable $\mathrm{Ca}^{2+}$ between 1972 and 2004. Among the eight core plots, two showed significant decreases in exchangeable $\mathrm{Ca}^{2+}$ between 1972 and 2004 in the 0 - to $15-\mathrm{cm}$ depth. The grand averages of exchangeable $\mathrm{Ca}^{2+}$ of the 23 soil plots did not differ significantly from the grand average of the eight core plots in either 1972 or 2004 in the 0 - to $15-\mathrm{cm}$ depth, and the changes between 1972 and 2004 were not significant in either case. In the 45- to 60-cm depth, seven of 19 soil plots showed significant decreases in exchangeable $\mathrm{Ca}^{2+}$ and one plot showed a significant increase in exchangeable $\mathrm{Ca}^{2+}$. Among the eight core plots, two showed significant decreases and one (the same one as in the larger database) showed a significant increase in exchangeable $\mathrm{Ca}^{2+}$. The grand averages of exchangeable $\mathrm{Ca}^{2+}$ of the 23 soil plots did not differ significantly from the grand average of the eight core plots in either 1972 or 2004 in the 45- to 60-cm depth, and the average changes between 1972 and 2004 were not significant in either case.

Changes in exchangeable $\mathrm{Mg}^{2+}$ across the watershed were consistently negative. In the $0-$ to $15-\mathrm{cm}$ depth, five of the 23 soil plots analyzed and three of the eight core plots showed significant decreases in exchangeable $\mathrm{Mg}^{2+}$ between 1972 and 2004. The grand averages of exchangeable $\mathrm{Mg}^{2+}$ of the 23 soil plots did not differ significantly from the grand average of the eight core plots in 1972, but the value for the core plots was significantly lower in 2004 (Table 2). The changes between 1972 and 2004 in the 0 - to $15-\mathrm{cm}$ depth were not significant among the 23 soil plots but were significant among the eight core plots. In the $45-$ to $60-\mathrm{cm}$ depth, 10 of 19 soil plots and three of the eight core plots showed significant decreases in exchangeable $\mathrm{Mg}^{2+}$. The grand averages of exchangeable $\mathrm{Mg}^{2+}$ of the 19 soil plots did not differ significantly from the grand average of the eight core plots in either 1972 or 2004 in the 0 - to $15-\mathrm{cm}$ depth, and the changes between 1972 and 2004 were significant in both cases.

\section{Changes in Soil Exchangeable Potassium, Calcium, and Magnesium in Core Plots, 1982 to 2004}

Changes in exchangeable $\mathrm{K}^{+}, \mathrm{Ca}^{2+}$, and $\mathrm{Mg}^{2+}$ in the eight core plots are shown in Fig. 2 to 4 and ANOVA analyses are given in Tables 3 and 4 . Table 3 provides analyses of the effects of year and depth within each plot, and Table 4 gives analyses of the overall changes among all plots, depths, and years. Measurements in the intervening years (1982 and 1993) between 1972 and 2004 in the core plots indicated that the observed increases in exchangeable $\mathrm{K}^{+}$ occurred primarily between 1972 and 1982, with little further change thereafter in most cases. Statistical analyses of the 1982 to 2004 data set (including all depths) showed that the effects of year were significant for exchangeable $\mathrm{K}^{+}$in only two core plots (26 and 237; Table 3 ). The changes in 


\section{Calcium}
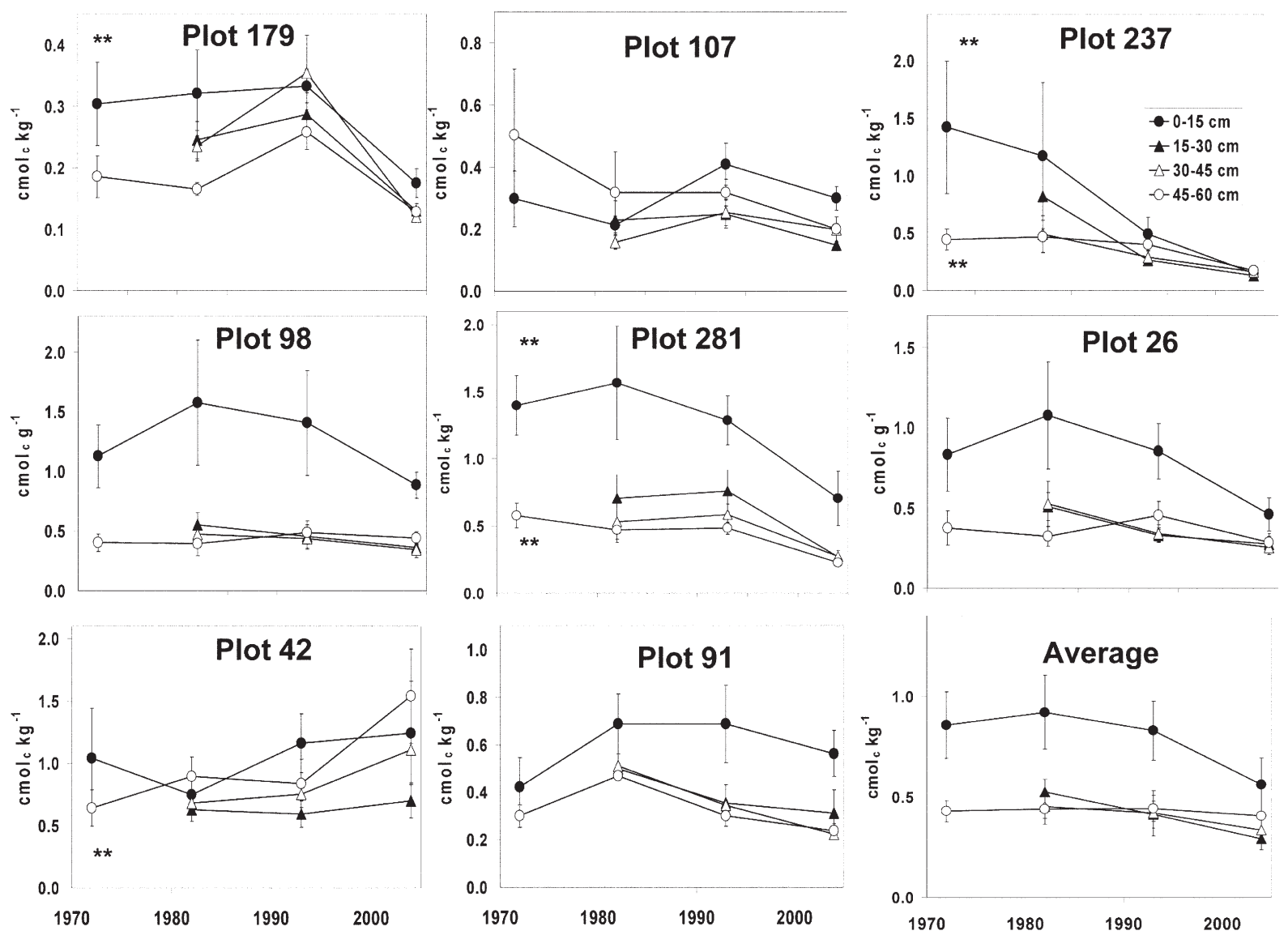

Fig. 3. Changes in soil exchangeable $\mathrm{Ca}^{2+}$ concentrations between 1972 and 2004 in the eight core plots. The panel labeled average shows the average values of all plots, using the plot average for each year. Standard errors are shown. Asterisks indicate significant differences in 1972 and 2004 analyses (0-15- and 45-60-cm depths only, unpaired Student's $t$-test, $* P \leq 0.05)$.

exchangeable $\mathrm{K}^{+}$in these two plots were not in the same direction, however: in Plot 26, exchangeable $\mathrm{K}^{+}$fluctuated with time in the surface depths and showed an increase in the 45 - to 60-cm depth, whereas in Plot 237 exchangeable $\mathrm{K}^{+}$showed a decrease between 1993 and 2004 at all depths. The average change in exchangeable $\mathrm{K}^{+}$among all plots was not statistically significant (Table 4).

The effects of year on exchangeable $\mathrm{Ca}^{2+}$ were significant in seven of the eight core plots (all but Plot 98; Table 3) as well as the average of all plots (Table 4). The changes in exchangeable $\mathrm{Ca}^{2+}$ were negative except for Plot 42 . The increase in exchangeable $\mathrm{Ca}^{2+}$ in Plot 42 no doubt contributed substantially to the significance of the plot $\times$ year interaction term (Table 4).

The effects of year on exchangeable $\mathrm{Mg}^{2+}$ were significant in six of the eight core plots (Table 3, Fig. 4) as well as the average of all plots (Table 4). Exchangeable $\mathrm{Mg}^{2+}$ decreased in all cases where the effects of year were statistically significant (Fig. 4).

\section{Changes in Ecosystem Potassium, Calcium, and Magnesium Contents in Core Plots, 1982 to 2004}

The average $\mathrm{K}$ contents of live trees, standing dead trees, O horizon, total above-soil materials (live trees + standing dead trees + downed logs + O horizon), and total ecosystem in the core plots changed significantly during the 22-yr sampling period (1982-2004) but the changes in CWD K content and soil exchangeable $\mathrm{K}^{+}$contents did not (Fig. 5A, Table 5). The average above-soil K increment $\left(49 \pm 20 \mathrm{~kg} \mathrm{ha}^{-1}\right)$ equaled $26 \%$ of the average soil exchangeable $\mathrm{K}^{+}$content in $1982\left(190 \pm 17 \mathrm{~kg} \mathrm{ha}^{-1}\right)$. Estimates of net leaching fluxes of $\mathrm{K}^{+}$(atmospheric deposition minus leaching) extrapolated across a period of $22 \mathrm{yr}$ from the 1983 to 1986 collection period (Johnson and Todd, 1990) averaged $74 \pm 19 \mathrm{~kg} \mathrm{ha}^{-1}$, or $39 \%$ of exchangeable $\mathrm{K}^{+}$, in 1982 . Despite the apparent pressures on soil exchangeable $\mathrm{K}^{+}$pools from the aboveground increment plus leaching (averaging $123 \mathrm{~kg} \mathrm{ha}^{-1}$ or $65 \%$ of soil exchangeable $\mathrm{K}^{+}$content in 1982), average net changes in exchangeable $\mathrm{K}^{+}$contents between 1982 and 2004 were small $\left(-6 \pm 9 \mathrm{~kg} \mathrm{ha}^{-1}\right)$ and nonsignificant. Soil total K pools $\left(18440 \pm 970 \mathrm{~kg} \mathrm{ha}^{-1}\right)$ measured in 1982 were nearly two orders of magnitude greater than exchangeable pools and thus a very low rate of weathering could have replenished any withdrawals of $\mathrm{K}^{+}$from the exchangeable pools (Fig. 5A).

The average Ca contents of live trees, standing dead trees, O horizon, total above-soil materials, and total ecosystem in the core plots changed significantly during the sampling period but the average changes in downed trees and soil exchangeable $\mathrm{Ca}^{2+}$ did not (Fig. 5B, Table 5). The average above-soil Ca increment of $497 \pm 138 \mathrm{~kg} \mathrm{ha}^{-1}$ equaled $86 \%$ of the exchangeable $\mathrm{Ca}^{2+}$ in $1982\left(577 \pm 92 \mathrm{~kg} \mathrm{ha}^{-1}\right)$. Average net leaching fluxes of $\mathrm{Ca}^{2+}\left(58 \pm 46 \mathrm{~kg} \mathrm{ha}^{-1}\right)$ were much smaller, equaling only $10 \%$ of exchangeable $\mathrm{Ca}^{2+}$ in 1982 . The average net change in soil exchangeable $\mathrm{Ca}^{2+}$ content between 1982 and 2004 (-178 $\pm 114 \mathrm{~kg} \mathrm{ha}^{-1}$ or $31 \%$ of the 1982 content) was much smaller 


\section{Magnesium}
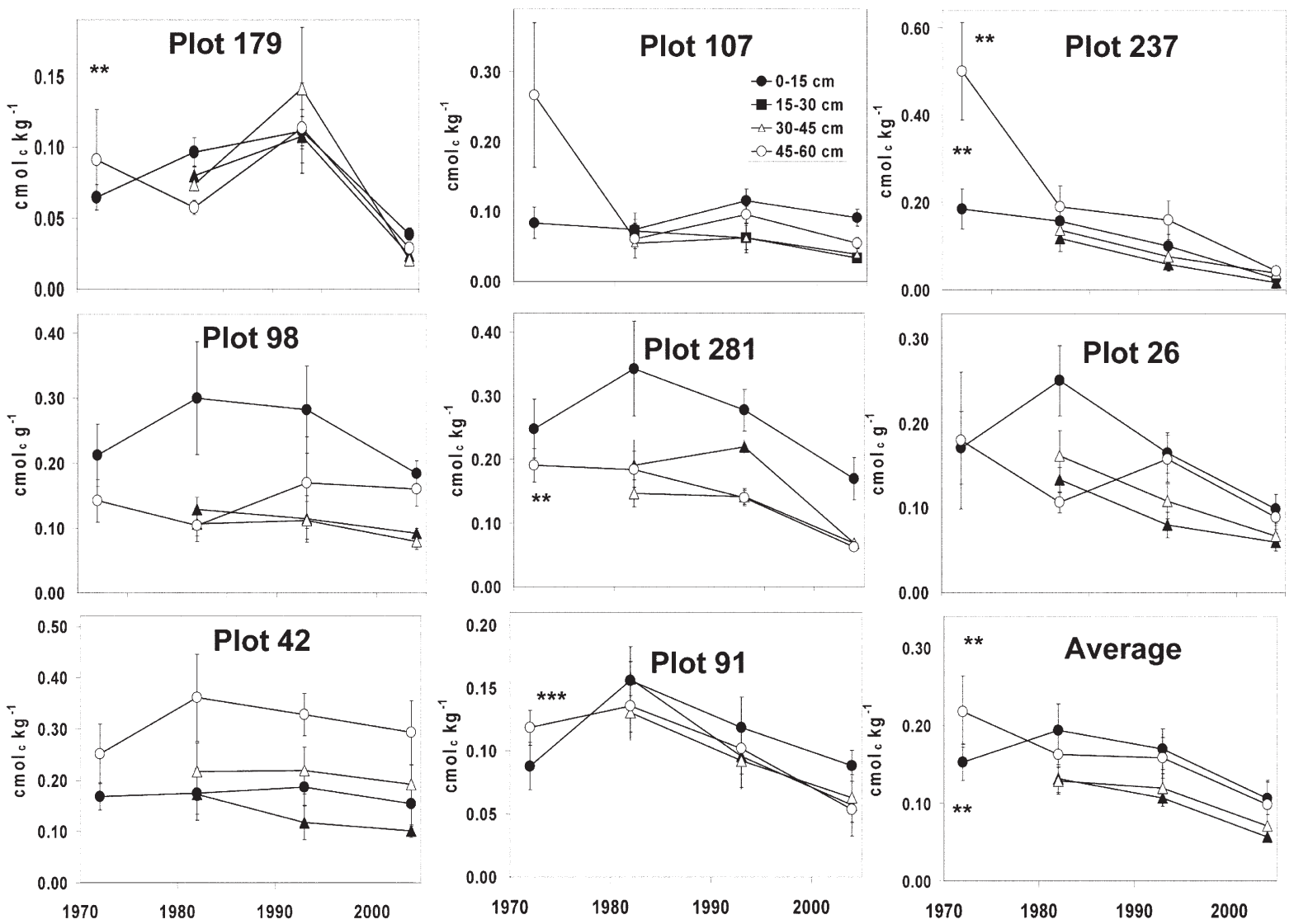

Fig. 4. Changes in soil exchangeable $\mathrm{Mg}^{2+}$ concentrations between 1972 and 2004 in the eight core plots. The panel labeled average shows the average values of all plots, using the plot average for each year. Standard errors are shown. Asterisks indicate significant differences in 1972 and 2004 analyses (0-15- and 45-60-cm depths only, unpaired Student's $t$-test, $* P \leq 0.05, * * P \leq 0.01)$.

than the above-soil increment plus leaching $\left(555 \mathrm{~kg} \mathrm{ha}^{-1}\right)$ and not statistically significant. Total soil Ca pools were small: the above-soil increment plus leaching equaled $26 \%$ of total soil Ca in $1982\left(2110 \pm 220 \mathrm{~kg} \mathrm{ha}^{-1}\right)$. Thus, weathering from the top $60 \mathrm{~cm}$ of the soil would not appear to be a probable source for replenishing $\mathrm{Ca}^{2+}$ removed from exchange sites. As hypothesized by Trettin et al. (1999), deep rooting into dolomite bedrock may have provided $\mathrm{Ca}$ in some cases where bedrock is relatively close to the surface; on ridge tops, however, bedrock can be as much as $30 \mathrm{~m}$ below the surface. Another source in some cases (i.e., Plot 42) may be the decomposition of Ca-rich CWD. This possibility is discussed in detail below.

The average $\mathrm{Mg}$ contents of live trees, standing dead trees, $\mathrm{O}$ horizon, total above-soil material, and soil exchange sites in the core plots changed significantly during the sampling period but the changes in downed tree and total ecosystem $\mathrm{Mg}$ did not (Fig. 5C, Table 5). The average above-soil Mg increment of $18 \pm 4 \mathrm{~kg} \mathrm{ha}^{-1}$ equaled only $19 \%$ of the soil exchangeable $\mathrm{Mg}^{2+}$ content in $1982\left(94 \pm 15 \mathrm{~kg} \mathrm{ha}^{-1}\right)$. Estimates of net fluxes of $\mathrm{Mg}^{2+}\left(100 \pm 25 \mathrm{~kg} \mathrm{ha}^{-1}\right)$ are much greater than the net above-soil increment and are approximately equal to exchangeable $\mathrm{Mg}^{2+}$ in 1982. Average net changes in the soil exchangeable $\mathrm{Mg}^{2+}$ contents between 1982 and $2004\left(-44 \pm 9 \mathrm{~kg} \mathrm{ha}^{-1}\right)$ were statistically significant but less than the net above-soil increment plus net leaching $\left(118 \mathrm{~kg} \mathrm{ha}^{-1}\right)$, suggesting either deep rooting or weathering from surface soils as sources for the replenishment of exchangeable $\mathrm{Mg}^{2+}$. Average soil total $\mathrm{Mg}$ in the top $60 \mathrm{~cm}\left(5990 \pm 440 \mathrm{~kg} \mathrm{ha}^{-1}\right)$ was large relative to exchangeable $\mathrm{Mg}^{2+}$ (Fig. 5 C).

\section{Tests of Hypotheses}

Hypothesis 1 (the eight core plots are representative of the more extensive soil sampling plots established in 1972) was supported by the comparisons of the average values of exchangeable $\mathrm{K}^{+}, \mathrm{Ca}^{2+}$, and $\mathrm{Mg}^{2+}$ in all the soil plots with those in the core plots. Of the 24 possible comparisons (12 comparisons of 1972 and 2004 concentrations and 12 comparisons of changes with time), only three showed significant differences between the soil and core plot averages. In one case (changes in $\mathrm{K}^{+}$in the $0-15-\mathrm{cm}$ depth), the difference between the two averages was due to a significant outlier; without the outlier, the changes with time in the soil plots would be statistically significant, as was found for the core plots.

Hypothesis 2 (the changes reported by Trettin et al. [1999] for the third sampling in 1993 would continue to 2004) was supported in part by the results of this study: with one notable exception, the declines in exchangeable $\mathrm{Ca}^{2+}$ and $\mathrm{Mg}^{2+}$ noted in the 1972 to 1993 samplings generally continued into 2004 . (Recall that Trettin et al. [1999] did not report on exchangeable $\mathrm{K}^{+}$.) The one major exception to this was Plot 42, where exchangeable $\mathrm{Ca}^{2+}$ (but not $\mathrm{Mg}^{2+}$ or $\mathrm{K}^{+}$) increased with time. We hypothesize that this was due to the decomposition of Ca-rich CWD from chestnut oak mortality in that case. The estimated Ca increase in CWD from downed trees in this plot 
Table 3. Analysis of variance probabilities for changes in soil concentrations of $\mathrm{K}^{+}, \mathrm{Ca}^{2+}$, and $\mathrm{Mg}^{2+}$ in the individual core plots between 1982 and 2004.

\begin{tabular}{|c|c|c|c|c|c|c|c|}
\hline \multirow{2}{*}{ Source } & \multirow{2}{*}{ df } & \multicolumn{2}{|c|}{$\mathrm{K}^{+}$} & \multicolumn{2}{|c|}{$\mathrm{Ca}^{2+}$} & \multicolumn{2}{|c|}{$\mathrm{Mg}^{2+}$} \\
\hline & & F ratio & $P$ & $F$ ratio & $P$ & $F$ ratio & $P$ \\
\hline \multicolumn{8}{|l|}{ Plot 26} \\
\hline Year & 2 & 5.058 & 0.010 & 5.822 & 0.005 & 16.182 & $<0.001$ \\
\hline Depth & 3 & 9.287 & $<0.001$ & 9.542 & $<0.001$ & 7.898 & 0.000 \\
\hline Year $\times$ depth & 6 & 2.219 & 0.054 & 1.261 & 0.290 & 2.726 & 0.021 \\
\hline \multicolumn{8}{|l|}{ Plot 42} \\
\hline Year & 2 & 1.532 & 0.225 & 3.611 & 0.034 & 0.969 & 0.386 \\
\hline Depth & 3 & 4.587 & 0.006 & 2.544 & 0.065 & 9.853 & $<0.001$ \\
\hline Year $\times$ depth & 6 & 0.218 & 0.970 & 0.633 & 0.703 & 0.127 & 0.993 \\
\hline \multicolumn{8}{|l|}{ Plot 91} \\
\hline Year & 2 & 2.862 & 0.066 & 5.088 & 0.010 & 13.587 & $<0.001$ \\
\hline Depth & 3 & 13.373 & $<0.001$ & 8.029 & $<0.001$ & 0.950 & 0.423 \\
\hline Year $\times$ depth & 6 & 0.591 & 0.736 & 0.252 & 0.956 & 0.171 & 0.984 \\
\hline \multicolumn{8}{|l|}{ Plot 98} \\
\hline Year & 2 & 1.569 & 0.218 & 1.766 & 0.181 & 1.123 & 0.333 \\
\hline Depth & 3 & 14.765 & $<0.001$ & 14.255 & $<0.001$ & 8.800 & $<0.001$ \\
\hline Year $\times$ depth & 6 & 0.771 & 0.596 & 0.716 & 0.638 & 0.721 & 0.635 \\
\hline \multicolumn{8}{|l|}{ Plot 107} \\
\hline Year & 2 & 4.244 & 0.019 & 4.470 & 0.015 & 3.703 & 0.030 \\
\hline Depth & 3 & 20.242 & $<0.001$ & 3.424 & 0.022 & 4.389 & 0.007 \\
\hline Year $\times$ depth & 5 & 1.029 & 0.415 & 1.290 & 0.275 & 0.860 & 0.529 \\
\hline \multicolumn{8}{|l|}{ Plot 179} \\
\hline Year & 2 & 2.643 & 0.081 & 35.278 & $<0.001$ & 25.361 & $<0.001$ \\
\hline Depth & 3 & 0.900 & 0.447 & 3.209 & 0.030 & 0.377 & 0.770 \\
\hline Year $\times$ depth & 6 & 1.212 & 0.315 & 1.181 & 0.331 & 0.567 & 0.755 \\
\hline \multicolumn{8}{|l|}{ Plot 237} \\
\hline Year & 2 & 5.532 & 0.006 & 8.103 & 0.001 & 17.410 & $<0.001$ \\
\hline Depth & 3 & 6.788 & 0.001 & 1.232 & 0.306 & 2.973 & 0.039 \\
\hline Year $\times$ depth & 6 & 0.566 & 0.755 & 0.810 & 0.566 & 0.474 & 0.825 \\
\hline \multicolumn{8}{|l|}{ Plot 281} \\
\hline Year & 2 & 0.886 & 0.418 & 9.513 & $<0.001$ & 17.433 & $<0.001$ \\
\hline Depth & 3 & 22.278 & $<0.001$ & 15.026 & $<0.001$ & 13.177 & $<0.001$ \\
\hline Year $\times$ depth & 6 & 0.371 & 0.894 & 0.801 & 0.573 & 0.759 & 0.605 \\
\hline
\end{tabular}

of the logging residues were not large enough to have caused significant changes in soil exchangeable $\mathrm{K}^{+}$or $\mathrm{Mg}^{2+}$, however, and no changes were found. The situation in Plot 42 is analogous to the logging residue study except that the residue was in the form of tree mortality in the latter case.

Hypothesis 3 (changes in exchangeable $\mathrm{Ca}^{2+}$ but not $\mathrm{Mg}^{2+}$ can be attributed to sequestration in above-soil biomass and detritus) was partially supported by the results of this study. Despite the pressure from the above-soil increment, and the fact that changes in soil exchangeable $\mathrm{Ca}^{2+}$ concentrations were significant in seven out of the eight core plots (Table 3) and among all core plots (Table 4), the average changes in soil exchangeable $\mathrm{Ca}^{2+}$ content were not statistically significant. The lack of significance in the average exchangeable $\mathrm{Ca}^{2+}$ content was specifically due to the anomalous increase in Plot 42. The value for the change in exchangeable $\mathrm{Ca}^{2+}$ content for Plot 42 does not qualify as a statistical outlier, but it is certainly anomalous, being the only positive value. If Plot 42 is omitted from the data set, the decreases in exchangeable $\mathrm{Ca}^{2+}$ content would average $-274 \pm 6 \mathrm{~kg} \mathrm{ha}^{-1}$ and the changes would be significant $(P=0.001)$.

The average change in soil exchangeable $\mathrm{Mg}^{2+}$ content was statistically significant and consistently in the negative direction, including in Plot 42 (Table 6). As in the past, the available nutrient budget data suggest that, on average, the decreases in soil exchangeable $\mathrm{Mg}^{2+}$ content can be attributed primarily to leaching, with a smaller contriwas very large (751 $\mathrm{kg} \mathrm{ha}^{-1}$; Table 6$)$ due to mortality and tree fall of Ca-rich chestnut oak, and some of the $\mathrm{Ca}$ contained in the woody tissues of this species could well have entered the soil during decomposition and accounted for the observed increase in exchangeable $\mathrm{Ca}^{2+}\left(493 \mathrm{~kg} \mathrm{ha}^{-1}\right)$. The inventory method used to calculate downed trees does not allow us to determine the degree to which this CWD has decomposed since it entered the latter category; however, we note that decomposition of CWD on and near Walker Branch proceeds at a relatively rapid rate. For example, we found that $>85 \%$ of the CWD left behind after clear-cut logging in a nearby site with similar soils and vegetation had decomposed during a period of $15 \mathrm{yr}$ (Johnson and Todd, 1998). The Ca released during the decomposition of the logging residues was fully accounted for by significant increases in exchangeable $\mathrm{Ca}^{2+}$ during the same time period. The $\mathrm{K}$ and $\mathrm{Mg}$ losses during decomposition

Table 4. Analysis of variance results for changes in soil exchangeable $\mathrm{K}^{+}, \mathrm{Ca}^{2+}$, and $\mathrm{Mg}^{2+}$ in the eight intensively sampled core plots for the period 1982 to 2004, including all depths.

\begin{tabular}{|c|c|c|c|c|c|c|c|}
\hline \multirow{2}{*}{ Source } & \multirow{2}{*}{ df } & \multicolumn{2}{|c|}{$\mathrm{K}^{+}$} & \multicolumn{2}{|c|}{$\mathrm{Ca}^{2+}$} & \multicolumn{2}{|c|}{$\mathrm{Mg}^{2+}$} \\
\hline & & $F$ ratio & $P$ & $F$ ratio & $P$ & $F$ ratio & $P$ \\
\hline Plot & 7 & 11.08 & $<0.001$ & 27.30 & $<0.001$ & 28.39 & $<0.001$ \\
\hline Depth & 3 & 64.14 & $<0.001$ & 30.23 & $<0.001$ & 16.65 & $<0.001$ \\
\hline Year & 2 & 1.08 & 0.341 & 11.30 & $<0.001$ & 40.77 & $<0.001$ \\
\hline Plot $\times$ year & 14 & 2.50 & 0.019 & 4.27 & $<0.001$ & 2.06 & 0.013 \\
\hline Depth $\times$ year & 6 & 1.68 & 0.124 & 1.96 & 0.069 & 0.69 & 0.660 \\
\hline
\end{tabular}

bution from sequestration in vegetation and detritus. The variability among individual plots is very high, however: above-soil $\mathrm{Mg}$ sequestration in two individual plots (98 and 107) equaled or exceeded the decreases in soil exchangeable $\mathrm{Mg}^{2+}$ content (Table 6). Estimated $\mathrm{Mg}^{2+}$ leaching rates were considerably greater than above-soil $\mathrm{Mg}$ sequestration rates in three of the four plots in which leaching was estimated. As was the case for $\mathrm{Ca}$, however, there is a significant anomaly: Plot 107, where net $\mathrm{Mg}^{2+}$ leaching was very low because of a very high degree of sulfate retention in the soil, thereby reducing the mobile anion component that must be present for cation leaching (Johnson and Todd, 1990). As in the case of Ca in Plot 42, this seemingly anomalous result is a real and explainable one, not simply noise in the data.

Another factor in the exchangeable $\mathrm{Mg}^{2+}$ decrease could be reduced atmospheric deposition. Records from the National Atmospheric Deposition Program site on Walker Branch show statistically significant declines in wet deposition of $\mathrm{Mg}^{2+}$ between 1981 and 2005 (Fig. $6)$. There was also a decline in wet deposition of $\mathrm{Ca}^{2+}$ but it was not statistically significant. There was no trend in wet deposition of $\mathrm{K}^{+}$.

Although we attribute the changes in exchangeable $\mathrm{Ca}^{2+}$ and $\mathrm{Mg}^{2+}$ to different causes (primarily vegetation uptake for $\mathrm{Ca}$ and leaching for $\mathrm{Mg}$ ), the changes in the soil contents of these two nutrients are generally correlated. This 


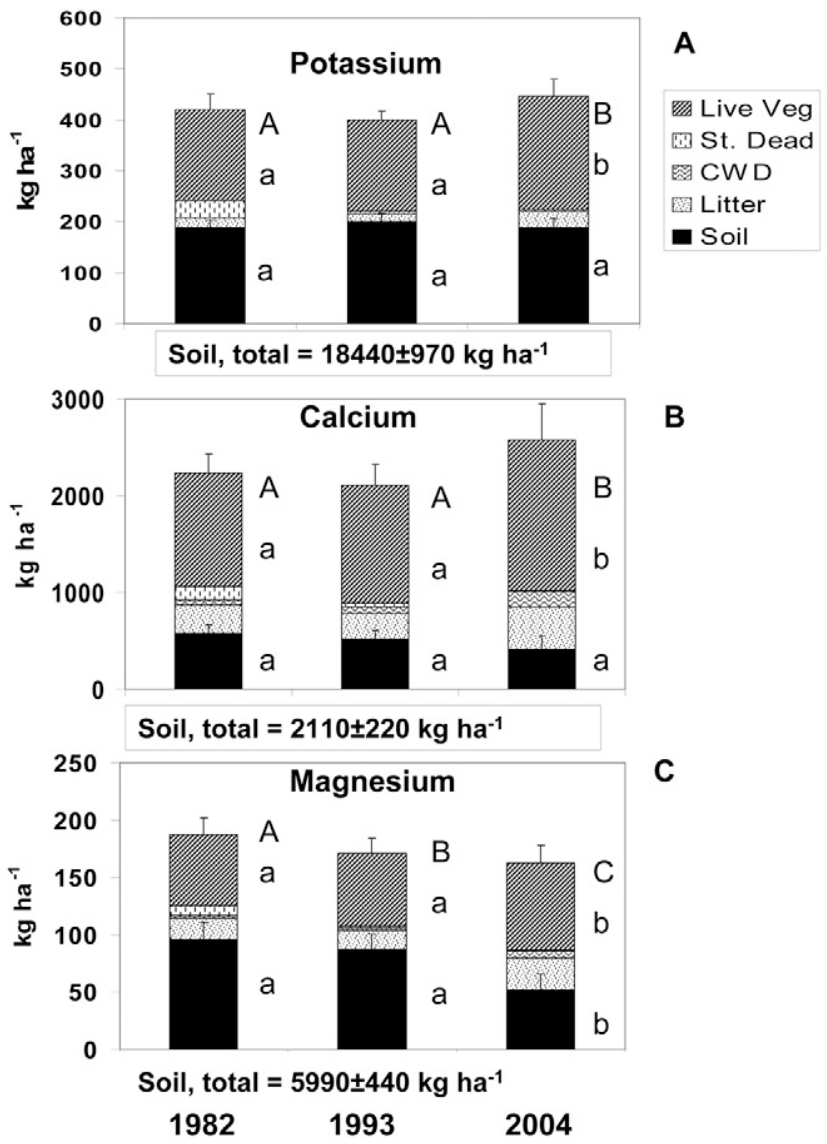

Fig. 5. Average (A) $\mathrm{K}^{+},(\mathrm{B}) \mathrm{Ca}^{2+}$, and (C) $\mathrm{Mg}^{2+}$ contents in live vegetation, standing dead vegetation, downed trees (coarse woody debris, CWD), $O$ horizon litter, and soil exchange sites in the core plots with time between 1982 and 2004. Standard deviations for soil exchangeable and total ecosystem contents are shown. Total soil contents measured in $\mathbf{1 9 8 2}$ are shown below each figure. Bars with the same lowercase letters are not significantly different $(P<0.05)$ in soil exchangeable and live tree contents with time; bars with the same uppercase letters are not significantly differenct in total above-soil contents (live vegetation + standing dead vegetation + down trees $+\mathrm{O}$ horizons) with time.

is shown in Fig. 7, which plots changes in exchangeable $\mathrm{Ca}^{2+}$ and $\mathrm{Mg}^{2+}$ against one another. Leaving Plot 42 aside, Fig. 7 shows that (i) the declines in exchangeable $\mathrm{Ca}^{2+}$ and $\mathrm{Mg}^{2+}$ are highly correlated $\left(r^{2}=0.82, P\right.$ $=0.003$ ), and (ii) the changes were greatest in soils with initially higher contents.

The examples of Ca in Plot 42 and Mg in Plot 107 raise the issue of averaging as a means of characterizing biogeochemical pools and processes. Recent studies have documented the importance of understanding the roles of "hot spots" and "hot moments" in soils, whereby plant roots can forage in nutrient-rich sites and abandon them when they are depleted (McClain et al., 2003; Schimel and Bennett, 2004). Such a strategy allows plants to "mine" soils for $\mathrm{N}$ that would otherwise be denied to them by microbial competition away from the hot spots. Averaging or bulking soils masks this important feature and thereby obfuscates our understanding of its importance. Similarly, averaging the changes in individual plots or individual cores within plots in this study masks real variability in soil changes
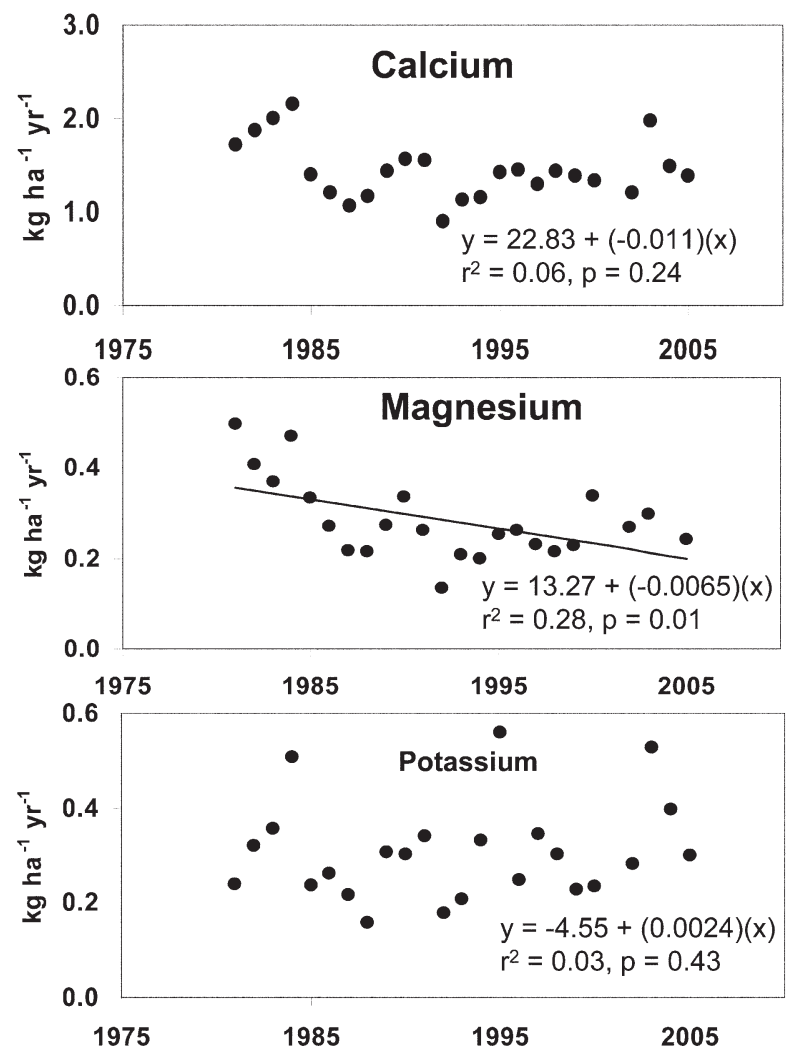

Fig. 6. Wet deposition of $\mathrm{Ca}^{2+}, \mathrm{Mg}^{2+}$, and $\mathrm{K}^{+}$on Walker Branch Watershed, 1982 to 2005. (source: National Atmospheric Deposition Program Office, Illinois State Water Survey, Champaign).

and the reasons for such changes. Thus, to say that average soil exchangeable $\mathrm{Ca}^{2+}$ content did not change on Walker Branch Watershed during the sampling period is not to say that no changes in soil exchangeable $\mathrm{Ca}^{2+}$ content occurred on the watershed. Had we bulked within or among plots, we would have reached very different and erroneous conclusions about soil changes in this site.

Table 5. Analysis of variance values for average changes in ecosystem $\mathrm{K}^{+}$, $\mathrm{Ca}^{2+}$, and $\mathrm{Mg}^{2+}$ contents between 1982 and 2004 .

\begin{tabular}{|c|c|c|c|c|c|c|c|}
\hline \multirow{2}{*}{ Source } & \multirow{2}{*}{ df } & \multicolumn{2}{|c|}{$\mathrm{K}^{+}$} & \multicolumn{2}{|c|}{$\mathrm{Ca}^{2+}$} & \multicolumn{2}{|c|}{$\mathrm{Mg}^{2+}$} \\
\hline & & $F$ ratio & $P$ & $F$ ratio & $P$ & $F$ ratio & $P$ \\
\hline \multicolumn{8}{|l|}{ Live vegetation } \\
\hline Plot & 7 & 12.95 & $<0.001$ & 19.23 & 0.003 & 18.65 & $<0.001$ \\
\hline Year & 3 & 6.52 & 0.010 & 8.75 & $<0.001$ & 15.30 & $<0.001$ \\
\hline \multicolumn{8}{|c|}{ Standing dead trees } \\
\hline Plot & 7 & 1.00 & 0.471 & 0.75 & 0.636 & 0.97 & 0.490 \\
\hline Year & 2 & 5.16 & 0.021 & 7.70 & 0.006 & 9.47 & 0.003 \\
\hline \multicolumn{8}{|l|}{ Downed trees } \\
\hline Plot & 7 & 3.04 & 0.036 & 3.79 & 0.016 & 3.02 & 0.037 \\
\hline Year & 2 & 2.47 & 0.120 & 1.25 & 0.309 & 1.63 & 0.230 \\
\hline \multicolumn{8}{|l|}{ O horizon } \\
\hline Plot & 7 & 2.02 & 0.125 & 5.34 & 0.004 & 6.88 & 0.001 \\
\hline Year & 2 & 8.42 & 0.004 & 8.96 & 0.003 & 13.84 & 0.005 \\
\hline \multicolumn{8}{|l|}{ Total above soil } \\
\hline Plot & 7 & 13.41 & $<0.001$ & 27.64 & $<0.001$ & 19.58 & $<0.001$ \\
\hline Year & 2 & 9.45 & 0.003 & 16.77 & $<0.001$ & 32.78 & $<0.001$ \\
\hline \multicolumn{8}{|l|}{ Soil } \\
\hline Plot & 7 & 7.41 & $<0.001$ & 7.15 & $<0.001$ & 16.63 & $<0.001$ \\
\hline Year & 2 & 2.62 & 0.108 & 2.05 & 0.153 & 15.46 & $<0.001$ \\
\hline \multicolumn{8}{|l|}{ Total ecosystem } \\
\hline Plot & 7 & 6.93 & $<0.001$ & 15.79 & $<0.001$ & 12.06 & $<0.001$ \\
\hline Year & 2 & 3.32 & 0.066 & 4.48 & 0.031 & 3.11 & 0.076 \\
\hline
\end{tabular}


Ca Change (kg ha-1)

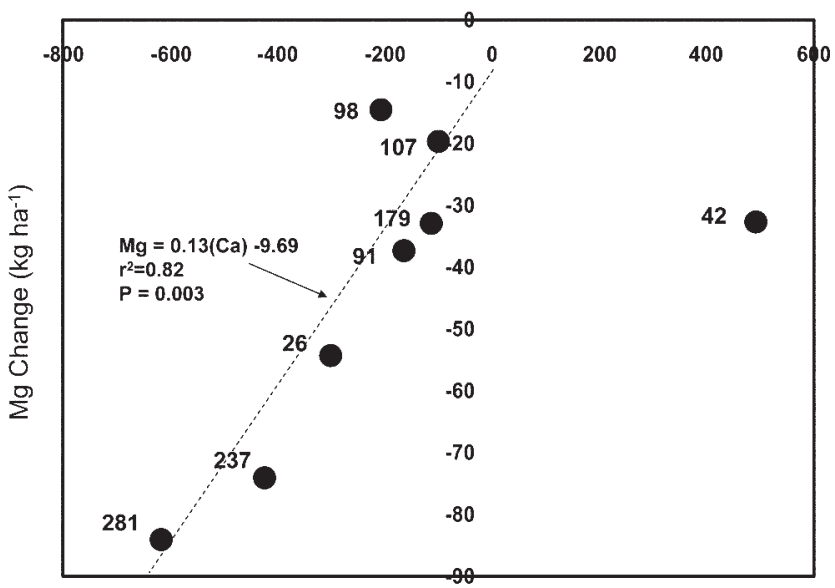

Fig. 7. Changes in soil exchangeable $\mathrm{Ca}^{2+}$ contents plotted against changes in exchangeable $\mathrm{Mg}^{2+}$ contents in the core plots. The dotted line shows the regression of soil $\mathrm{Mg}^{2+}$ against $\mathrm{Ca}^{2+}$ contents for all but Plot 42.

\section{SUMMARY AND CONCLUSIONS}

1. The eight core plots sampled intensively during the last $32 \mathrm{yr}$ for changes in soil nutrients are, with minor exception, representative of soils from a larger subset of 24 soil sampling plots distributed across Walker Branch Watershed and sampled twice during this interval.

2. With one exception, the declines in soil exchangeable $\mathrm{Ca}^{2+}$ and $\mathrm{Mg}^{2+}$ concentrations noted in previous studies from the eight core plots (Johnson et al., 1988; Trettin et al., 1999) continued into the fourth sampling in 2004. The major exception to these patterns was in the case of exchangeable $\mathrm{Ca}^{2+}$, where significant increases in concentration were noted and attributed to Ca release from decomposing CWD in one plot.

3. As noted in past studies, sequestration in above-soil material (live and dead trees plus detritus components) appeared to be the greatest factor causing declines in exchangeable $\mathrm{Ca}^{2+}$ content, whereas leaching appeared to be the greatest factor causing declines in exchangeable $\mathrm{Mg}^{2+}$ content. There were, however, important exceptions to this general pattern in specific plots.

This study shows that soil sampling at long intervals can mask important temporal variations, and that averaging or bulking among or within plots can mask significant and important spatial patterns in soil change. The variations in soil changes on Walker Branch Watershed-both spatial and temporal — are real and informative, and should not be treated simply as statistical noise.

\section{ACKNOWLEDGMENTS}

This research was supported by the U.S. Department of Energy's Program for Ecosystem Research in the Office of Science, Office of Biological and Environmental Research, under Contract DEAC05-00OR22725 with UT-Battelle, and the Nevada Agricultural Experiment Station, Publication no. 52077062. We thank Pat Mulholland for many helpful comments on the manuscript and Allen McBride for valuable assistance in the field and laboratory.

Table 6. Net changes in the $\mathrm{K}^{+}, \mathrm{Ca}^{2+}$, and $\mathrm{Mg}^{2+}$ contents in live trees, standing dead trees, downed trees, $\mathrm{O}$ horizon, total above-soil (AS) increment (live trees + standing dead trees + down trees + O horizon), soil exchange sites, and the total ecosystem in the core plots between 1982 and 2004. Also shown are extrapolated estimates of atmospheric deposition minus leaching from data collected from selected plots by Johnson and Todd (1990). Standard errors are shown for averages of all plots.

\begin{tabular}{|c|c|c|c|c|c|c|c|c|c|}
\hline \multirow{2}{*}{ Component } & \multicolumn{9}{|c|}{ Net change } \\
\hline & Plot 26 & Plot 42 & Plot 91 & Plot 98 & Plot 107 & Plot 179 & Plot 237 & Plot 281 & Avg. \pm SE \\
\hline & & & & & kg ha & & & & \\
\hline & & & & & $\underline{\mathrm{K}} \pm$ & & & & \\
\hline Live trees & -10 & 46 & 9 & 58 & 169 & 33 & 37 & 19 & $45 \pm 19$ \\
\hline Standing dead trees & -21 & -14 & -38 & -9 & -43 & -13 & -5 & -9 & $-19 \pm 5$ \\
\hline Downed trees & 10 & 71 & 7 & 5 & 4 & 0 & -1 & -5 & $11 \pm 9$ \\
\hline O horizon & 12 & -9 & 27 & 8 & 24 & 0 & 32 & 14 & $14 \pm 5$ \\
\hline Total AS & -25 & 93 & 5 & 61 & 154 & 20 & 63 & 20 & $49 \pm 20$ \\
\hline Soil exchange sites & 22 & -40 & -31 & 21 & -14 & -5 & -25 & 28 & $-6 \pm 9$ \\
\hline Total ecosystem & -3 & 53 & -27 & 82 & 140 & 14 & 38 & 47 & $43 \pm 18$ \\
\hline Deposition - leaching & -84 & & & -105 & 21 & -126 & & & $-74 \pm 23$ \\
\hline & & & & & $\underline{\mathrm{Ca}} \underline{2}$ & & & & \\
\hline Live trees & 134 & 151 & 151 & 528 & 1214 & 423 & 484 & 43 & $391 \pm 134$ \\
\hline Standing dead trees & -71 & -107 & -321 & -72 & -318 & -80 & -45 & -68 & $-135 \pm 41$ \\
\hline O horizon & 165 & -115 & 268 & 318 & 328 & -3 & 123 & 137 & $153 \pm 55$ \\
\hline Total AS & 260 & 581 & 140 & 808 & 1252 & 315 & 541 & 79 & $497 \pm 138$ \\
\hline Soil exchange sites & -299 & 493 & -163 & -207 & -100 & -112 & -614 & -422 & $-178 \pm 114$ \\
\hline Total ecosystem & -39 & 1174 & -23 & 601 & 1153 & 203 & -73 & -344 & $332 \pm 205$ \\
\hline Deposition - leaching & -189 & & & -21 & 105 & -126 & & & $-58 \pm 46$ \\
\hline & & & & & $\underline{M g} \underline{2}$ & & & & \\
\hline Live trees & 9 & 13 & -1 & 15 & 31 & 15 & 17 & 7 & $13 \pm 3$ \\
\hline Standing dead trees & -4 & -7 & -18 & -2 & -15 & -4 & -2 & -7 & $-7 \pm 2$ \\
\hline Downed trees & 5 & 23 & 2 & 1 & 2 & -1 & -2 & -2 & $4 \pm 3$ \\
\hline O horizon & 14 & -8 & 13 & 6 & 15 & 7 & 16 & 12 & $9 \pm 3$ \\
\hline Total AS & 18 & 21 & -4 & 21 & 33 & 17 & 28 & 10 & $18 \pm 4$ \\
\hline Soil exchange sites & -54 & -33 & -37 & -15 & -20 & -33 & -84 & -74 & $-44 \pm 9$ \\
\hline Total ecosystem & -36 & -12 & -41 & 6 & 13 & -16 & -56 & -64 & $-26 \pm 10$ \\
\hline Deposition - leaching & -105 & & & -168 & 0 & -126 & & & $-100 \pm 25$ \\
\hline
\end{tabular}




\section{REFERENCES}

Alban, D.H. 1982. Effects of nutrient accumulation by aspen, spruce, and pine on soil properties. Soil Sci. Soc. Am. J. 46:853-861.

Bailey, S.W., S.B. Horsley, and R.P. Long. 2005. Thirty years of change in forest soils of the Allegheny Plateau, Pennsylvania. Soil Sci. Soc. Am. J. 69:681-690.

Carmer, S.G., and M.R. Swanson. 1973. An evaluation of ten pairwise multiple comparison procedures by Monte Carlo methods. J. Am. Stat. Assoc. 68:66-74

Falkenggren-Grerup, U., and H. Eriksson. 1990. Changes in soil, vegetation, and forest yield between 1947 and 1988 in beech and oak sites of southern Sweden. For. Ecol. Manage. 38:37-53.

Falkenggren-Grerup, U., and G. Tyler. 1992. Changes since 1950 of mineral pools in the upper C-horizon of Swedish deciduous forest soils. Water Air Soil Pollut. 38:37-53.

Grigal, D.F., and R.A. Goldstein. 1971. An integrated ordination-classification analysis of an intensively sampled oak-hickory forest. J. Ecol. 59:481-492.

Hallbacken, L., and C.O. Tamm. 1986. Changes in soil acidity from 1927 to 1982 84 in a forest area of southwest Sweden. Scand. J. For. Res. 1:219-232.

Harris, W.F., R.A. Goldstein, and G.S. Henderson. 1973. Analysis of forest biomass pools, annual primary production, and turnover of biomass for a mixed deciduous forest watershed. p. 41-64. In H. Young (ed.) IUFRO biomass studies: Mensuration, growth and yield. Univ. of Maine Press, Orono.

Henderson, G.S., and W.F. Harris. 1975. An ecosystem approach to characterization of the nitrogen cycle in a deciduous forest watershed. p. 179-193. In B. Bernier and C.H. Winget (ed.) Forest soils and land management.: Presses de l'Universite Laval, Quebec City, QB, Canada.

Henderson, G.S., W.T. Swank, J.B. Waide, and C.C. Grier. 1978. Nutrient budgets of Appalachian and Cascade region watersheds: A comparison. For. Sci. 24:385-397.

Johnson, A.H., S.B. Andersen, and T.G. Siccama. 1994. Acid rain and soils of the Adirondacks: I. Changes in pH and available calcium, 1930-1984. Can. J. For. Res. 24:39-45.

Johnson, D.W. 2005. Comments on "Thirty years of change in forest soils of the Allegheny Plateau, Pennsylvania.”. Soil Sci. Soc. Am. J. 69:2077.

Johnson, D.W., G.S. Henderson, and D.E. Todd. 1988. Changes in nutrient distribution in forests and soils of Walker Branch Watershed, Tennessee, over an eleven-year period. Biogeochemistry 5:275-293.

Johnson, D.W., and D.E. Todd. 1998. The effects of harvesting on long-term changes in nutrient pools in a mixed oak forest. Soil Sci. Soc. Am. J. 62:1725-1735.

Johnson, D.W., and D.E. Todd. 1990. Nutrient cycling in forests of Walker Branch Watershed: Roles of uptake and leaching in causing soil change. J. Environ. Qual. 19:97-104.

Johnson, D.W., D.E. Todd, Jr., C.F. Trettin, and J.S. Sedinger. 2007. Soil carbon and nitrogen changes in forests of Walker Branch Watershed, 1972 to 2004. Soil Sci. Soc. Am. J. 71:1639-1646.

Johnson, D.W., and R.I. Van Hook (ed.). 1989. Analysis of biogeochemical cycling processes in Walker Branch Watershed. Springer-Verlag, New York.

Johnson, D.W., D.C. West, D.E. Todd, and L.K. Mann. 1982. Effects of sawlog vs. whole-tree harvesting on the nitrogen, phosphorus, potassium, and calcium budgets of an upland mixed oak forest. Soil Sci. Soc. Am. J. 46:1304-1309.

Knoepp, J.D., and W.T. Swank. 1994. Long-term soil chemistry changes in aggrading forest ecosystems. Soil Sci. Soc. Am. J. 58:325-331.

Lietzke, D.A. 1994. Soils of Walker Branch Watershed. ORNL TM-11606. Oak Ridge Natl. Lab., Oak Ridge, TN.

McClain, M.E., E.W. Boyer, C.L. Dent, S.E. Gergel, N.B. Grimm, PmS. Groffman, S.C Hart, J.W. Harvey, C.A. Johnston, E. Mayorga, W.H. McDowell, and G. Pinay. 2003. Biogeochemical hot spots and hot moments at the interface of terrestrial and aquatic ecosystems. Ecosystems 6:301-312.

Renze, J. 2007. Outlier. Available at mathworld.wolfram.com/Outlier.htm (verified 2 Aug. 2998). Wolfram Research, Champaign, IL.

Richter, D.D., and D. Markewitz. 2001. Understanding soil change: Soil sustainability over millennia, centuries, and decades. Cambridge Univ. Press, Cambridge, UK.

Richter, D.D., D. Markewitz, H.L. Allen, R. April, P.R. Heine, and R. Urrego. 1994. Soil chemical change during three decades in an old-field loblolly pine (Pinus taeda L.) ecosystem. Ecology 75:1463-1473.

Schimel, J.P., and J. Bennett. 2004. Nitrogen mineralization: Challenges of a changing paradigm. Ecology 85:591-602.

Trettin, C.A., D.W. Johnson, and D.E. Todd, Jr. 1999. Forest nutrient and carbon pools: A 21-year assessment. Soil Sci. Soc. Am. J. 63:1436-1448. 